\title{
Q's message to the peasantry and poor: Considering three texts in the Sayings Gospel
}

Author:
Llewellyn Howes ${ }^{1}$
Affiliation:
'Department of Religion
Studies, Faculty of
Humanities, University of
Johannesburg, South Africa
Corresponding author:
Llewellyn Howes,
llewellynhowes@gmail.com
Dates:
Received: 27 Mar. 2018
Accepted: 29 May 2018
Published: 14 Jan. 2019
mobile device
to read online.
How to cite this article:
Howes, L., 2019, 'Q's
message to the peasantry
and poor: Considering three
texts in the Sayings Gospel',
HTS Teologiese Studies/
Theological Studies 75(3),
a4992. https://doi.org/
10.4102/hts.v75i3.4992
Copyright:
@ 2019. The Authors.
Licensee: AOSIS. This work
is licensed under the
Creative Commons
Attribution License.

This article aims to argue that the Sayings Gospel $\mathrm{Q}$ has a unique message for the peasantry and poor of ancient society. The intention of this article is to uncover the intended message of three particular $Q$ texts for the peasantry and poor, namely $Q$ 7:24-28, Q 10:5-9 and Q 11:9-13.

\section{Introduction}

In my view, the Sayings Gospel $Q$ has a unique message for the peasantry ${ }^{1}$ and poor $^{2}$ of ancient

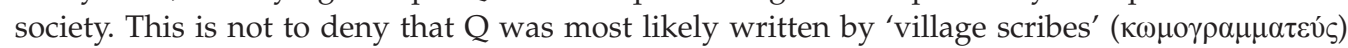
(see Arnal 2001; Kloppenborg 1991; cf. Bazzana 2015; Rollens 2014). In general terms, I tend to agree with the 'village scribe' hypothesis. Yet, unlike some proponents of this hypothesis, I do not perceive any contradiction between the idea that the authors of $Q$ were socio-economic 'middling' figures, to use the vocabulary of Rollens (2014), on the one hand, and the idea that the primary audiences of $\mathrm{Q}$ were made up of the peasantry and poor, on the other hand. The aim of this article is to uncover the intended message of three particular $Q$ texts for the peasantry and poor. The texts chosen for this analysis are Q 7:24-28, Q 10:5-9 and Q 11:9-13.

It is perhaps necessary to make one more point of clarification before the analysis proper may commence. It has sometimes been claimed that references in texts like Q 6:20 to 'the poor' or to poverty should be read against the background of the $Q$ people's abandonment of their traditional families to join the symbolic family of God, that is, the Q movement (Howes 2015:147; Moxnes 2003:62-63, 114; Piper 2000:242, 251, 252; Schottroff 1995:360; cf. Jacobson 2000:195; Van Aarde 2014:4; see Cromhout 2015:1-6). I agree that many of the Q people (referring here specifically to the audience of $Q$, not necessarily the authors of $Q$ ) were in all likelihood economically and socially less fortunate, and that this was a result of two simultaneous factors, namely that many people left their traditional homes to join the $\mathrm{Q}$ movement and that many people who gravitated towards the Q movement were already poor and marginalised (see Howes 2015:144-150). The message of $Q$ would have resonated particularly with these unfortunate members of the $\mathrm{Q}$ movement. This does not, however, mean that $\mathrm{Q}$ texts on poverty should be interpreted as if they were exclusively directed at these insiders. There is no reason why these texts could not also have intended a wider reach. On the one hand, many texts in Q (especially in Kloppenborg's formative stratum) seem unconcerned with social boundary demarcation and more concerned with Israel in toto. As such, many of these texts seem to have a more general applicability. On the other hand, many texts in Q seem to have some type of 'missionary' intent, so that Q's message to the peasantry and poor might have been a way to attract new members. At any rate, reading these texts as directed at the peasantry and poor in general does not take away from their applicability to the $\mathrm{Q}$ people in particular. Likewise, reading these texts as directed at the $\mathrm{Q}$ people in particular does not invalidate their meaningfulness for a wider audience.

Finally, it should never be forgotten that all sociological reconstructions of the Q people, including both the 'family abandonment' scenario and the 'village scribe' hypothesis, remain constructs based on imprecise clues from the text. To my mind, both of these constructs are convincing, but that should not lead to a situation where the most obvious and literal reading of any particular text is abandoned in favour of a reading that is based on some predetermined social construct.

\footnotetext{
1.The term 'peasantry' intends specifically ancient peasants, meaning ancient people who owned agricultural smallholdings and made a living by cultivating this land. For the sake of convenience, I use the term in this article to also include people who did not make a living by means of agricultural activities, but who were from the same socio-economic echelon, like, for example, fishermen. The overwhelming majority of people from this echelon were nonetheless peasants.

2.All references to 'the poor' (oi $\pi \tau \omega x \circ i$ ) have in mind those people who rank below the peasantry, including women without patriarchs, children without parents and families without land. A significant proportion of this group would have consisted of former peasants. As a result of exploitative debt contracts and usurious interest rates, many peasants were forced into indebtedness, which initiated a downwards spiral of control by creditors, loss of land, starvation and ending up as day-labourers, beggars or bandits (Arnal 2001:139-140, 146; Freyne 2000:205; Horsley 1995a:43; 1995b:60, 215-216, 219; Moxnes 2003:150; Oakman 2008:21, 25, 224).
}

Note: The collection entitled 'Eben Scheffler Festschrift', sub-edited by Jurie H. le Roux (University of Pretoria) and Christo Lombaard (University of South Africa). 
For example, the beatitude in Q 6:20b literally speaks both to and about 'the poor' (oi $\pi \tau \omega \chi o i)$. That is the information available to the interpreter. Certainly, the Q people would in all likelihood have identified especially with this term for a variety of sociological and perhaps other reasons, but that does not take away from the fact that the beatitude speaks specifically about 'the poor' and only 'the poor.' Designations like 'the family of God' or 'the children of God' do not appear in the beatitude and are only read into the literal text based on some predetermined social construct. ${ }^{3}$ The unqualified use of the term 'the poor' should be the first clue that the text might have a wider applicability than merely the $\mathrm{Q}$ people or the poor within the ranks of the $Q$ people. At any rate, the current intent is not to analyse $Q$ 6:20b, but rather Q 7:24-28, Q 10:5-9 and Q 11:9-13. Such analysis may now begin, attempting in the first place to read the selected texts at face value.

\section{Q 7:24-28}

${ }^{24}$ And when they had left, he began to talk to the crowds about John: What did you go out into the wilderness to look at? A reed shaken by the wind? ${ }^{25}$ If not, what did you go out to see? A person arrayed in finery? Look, those wearing finery are in kings' houses. ${ }^{26}$ But «then» what did you go out to see? A prophet? Yes, I tell you, even more than a prophet! ${ }^{27}$ This is the one about whom it has been written: Look, I am sending my messenger ahead of you, who will prepare your path in front of you. ${ }^{28} \mathrm{I}$ tell you: There has not arisen among women's offspring «anyone» who surpasses John. Yet the least significant in God's kingdom is more than he.

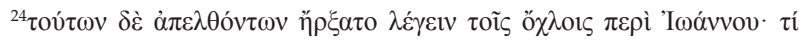

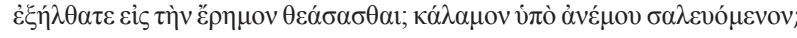

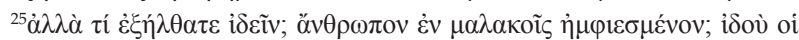

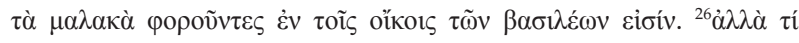

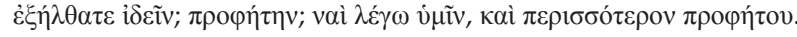

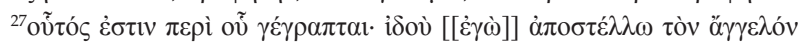

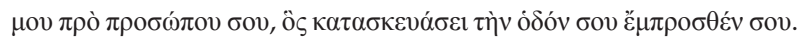

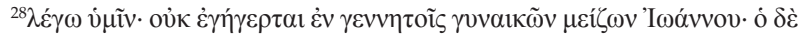

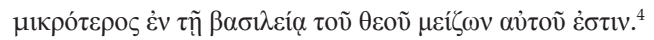

This pericope is in the first place a rhetorical exposition of the identity of John the Baptist (Johnson-DeBaufre 2005:69). The rhetorical questions and emphatic statement in verse 25 imply that John was not royal or wealthy (Bazzana 2015:273; Ra 2016:117) and that he did not mix with the likes of these people (Johnson-DeBaufre 2005:70) - facts that were well known to the early followers of both John and Jesus. In part, it is argued by this $\mathrm{Q}$ pericope that John's humble socioeconomic stature does not repudiate him as a prophet. Despite his lowly appearance, or perhaps because of it, he is

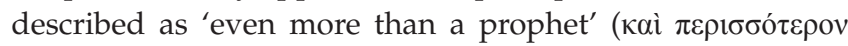

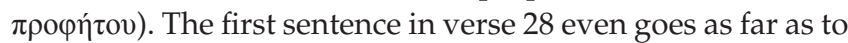
claim that John is the most significant person ever born (Catchpole 1993:65).

3. It is true that the inaugural sermon is introduced in $Q 6: 20$ a by referring to the 'disciples' ( $\mu \alpha \theta n \tau \alpha \dot{c})$ ), but this does not necessarily mean that these disciples should be conflated with 'the poor,' either fully or partially. The disciples are referenced here as the imagined historic audience who were listening to the inaugural sermon, some of whom would undoubtedly have been better off economically and socially, and others of whom would not have been part of the $Q$ movement, either at that moment or later on. Finally, the reference to the disciples takes place outside the boundaries of the inaugural sermon and its first logion.

4.All reconstructions and translations of $Q$ texts in this article are from the Critical Edition of Q (Robinson, Hoffmann \& Kloppenborg 2000, 2002).
John's significance should be understood not only in light of his own socio-economic paucity but also in light of the socioeconomic surplus of other leaders (cf. Catchpole 1993:66). John is deliberately contrasted with 'those who wear finery'

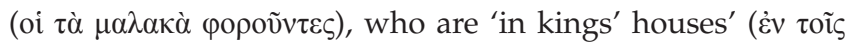

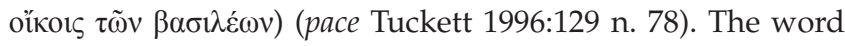
translated here as 'finery' ( $\mu \alpha \lambda \alpha \kappa o ́ s)$ literally means 'soft' and refers to the luxurious clothing of rich people (Davies \& Allison 1991:248; Louw \& Nida 1993:705, domain 79.100; Nolland 2005:455; cf. Horsley 1999:296). Bock (1994:671) paraphrases verse 25 as follows: 'Did you journey to the desert to see a man from the wealthy class who dressed well?' Luke develops the reference to luxurious clothing further by adding that the people who wear these clothes subsist 'in glorious apparel' ( $\dot{\varepsilon} v$ i $\mu \alpha \tau 1 \sigma \mu \tilde{\varphi} \dot{\varepsilon} v \delta$ ó $\xi \omega)$ and 'have luxury'

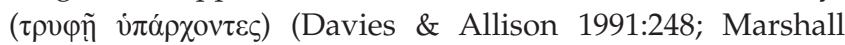
1978:294; Vaage 1994:98; cf. Bock 1994:671; Horsley 1999:296; Jacobson 1992:114). In the latter part of this Q verse, 'king's houses' (oi oĩko1 $\tau \tilde{\omega} v \beta \alpha \sigma i \lambda \varepsilon \dot{\omega} \omega v$ ) obviously refers to palaces (Bock 1994:671; Horsley 1999:240, 296; Johnson-DeBaufre 2005:70; Joseph 2012:86; Ra 2016:117; Vaage 1994:97). The Baptist is in other words contrasted specifically with political leaders who live in socio-economic abundance (Piper 2000:235-236; Rollens 2014:193; cf. Marshall 1978:294). It is claimed that, despite appearances, John's significance by far outweighs the significance of these wealthy leaders (cf. Vaage 2001:483).

Implicit in this rhetoric is the message that socio-economic and politico-religious stature does not determine one's worth in the kingdom of God. ${ }^{5}$ In fact, the mocking and derogatory tone of this $Q$ passage (esp. verse 25) would suggest that wealth and status were regarded with an attitude of disdain (Horsley 1999:98; cf. Arnal 2001:46; Piper 2000:261 n. 128; see Valantasis 2005:87-89). If Theissen (1986:43-55) is correct that

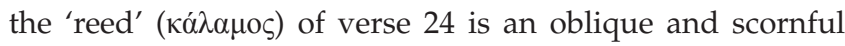
reference to Herod Antipas, it would follow that also this verse derides those with wealth and status, drawing specific attention to the political ruler who persecuted John (Horsley 1999:98, 240; cf. Allison 2000:223; Casey 2002:117; Davies \& Allison 1991:247 n. 54; Luz 2001:138; Nolland 2005:454; Piper 1989:125; 2000:236; Ra 2016:116; Tuckett 1996:129 n. 78). Some scholars view the reference to 'a reed shaken in the wind' as a metaphor for a commonplace, unexceptional event (e.g. Casey 2002:117; Davies \& Allison 1991:247; cf. Nolland 2005:454-455; Vaage 1994:96;). ${ }^{6}$ It is not impossible that both meanings of this metaphor are simultaneously intended, so that Herod (and other elites) is portrayed as being ordinary and unremarkable despite his power and prestige. The 'finery' of verse 25 is probably also a depreciating reference to Herod's courtiers and/or other elites (Davies \& Allison 1991:248; Vaage 1994:100; cf. Bock 1994:671; Horsley 1999:98; Marshall 1978:294; Piper 1989:125). The specific use of the word 'finery' ( $\mu \alpha \lambda \alpha \kappa o ́ s)$, which, as we saw, literally means

5.That the rhetoric in this pericope should be understood in terms of God's kingdom is made explicit in verse 28.

6.Other metaphorical interpretations have also been proposed (e.g. JohnsonDeBaufre 2005:69-70). Some interpreters prefer a strictly literal interpretation (e.g. Bock 1994:670-671; Nolland 2005:454-455). 
'soft,' is not insignificant in this context. It is comparable to the scoffing descriptions of 'palaces-dwellers' and other elites by the Cynics, who often mocked these people by making reference to their 'softness' and the fact that they like 'soft things,' including especially soft clothes (see Vaage 1994:97-100; cf. Robinson 1996:90; Rollens 2014:193; Tuckett 1996:129 n. 78). Given all the imagery implied by Q 7:24-25, it is little wonder that the Gospel of Thomas (78) interprets these logia in no uncertain terms as critique against the wealthy (Allison 2010:130). Over against the derogatory references to royal wealth, John's socio-economic and politico-religious insignificance is portrayed by $\mathrm{Q}$ as an asset, as if it increases his stature in God's kingdom (cf. Vaage 2001:483). Q's Jesus thereby turns the tables on the ancient system of honour and shame. Attributes that would typically afford one honour in ancient society are here portrayed as at best irrelevant and at worst detrimental. As in Q 6:29-30, Q's Jesus also challenges the foundations of ancient Jewish wisdom, according to which material success was a sign of divine blessing.

The second sentence in verse 28 claims that the 'least

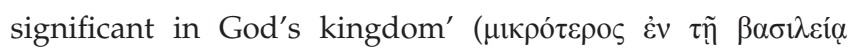

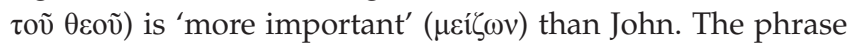
'least significant in God's kingdom' can be understood in one of two ways. Either it refers to those in God's kingdom who are less significant than others in God's kingdom, or it refers to those in God's kingdom who are insignificant according to societal standards. The former understanding presupposes a hierarchy operative within the in-group, while the latter does not. I prefer the latter understanding, which is supported by the fact that the pericope seems otherwise very concerned with the issue of social hierarchy within society at large, but not at all with the issue of social hierarchy within God's kingdom. In other words, 'more important' $(\mu \varepsilon i \zeta \omega v)$ should be understood in terms of social superiority (Louw \& Nida

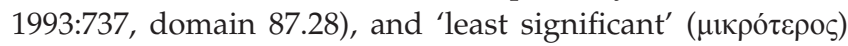
should be understood in the superlative sense as referring to a group (or rather, a class) of people ( Bock 1994:675; Davies \& Allison 1991:251; Luz 2001:139; Marshall 1978:296; Nolland 2005:457; Ra 2016:199; pace, e.g. Catchpole 1993:68-70; Hartin 2015:124). In all likelihood, the 'least significant' denotes those at the bottom of the ancient socio-economic totem pole (Johnson-DeBaufre 2005:77, 167; cf. Casey 2002:122). The claim in the second sentence of verse 28 that the least significant are more important than John is a deliberate contradiction of the claim in the first sentence of verse 28 that John is the most significant person ever born (Catchpole 1993:64; Marshall 1978:293; see Robinson 1998b:230-231; cf. Catchpole 1993:66; Davies \& Allison 1991:251; JohnsonDeBaufre 2005:75-76; Luz 2001:138-139; Ra 2016:42-43, 199; Tuckett 1996:130, 134). The point of this deliberate contradiction is to explain that even if John is the greatest person ever born, such significance means little in the kingdom of God (Johnson-DeBaufre 2005:77). Directly after claiming that John is the most important person ever, his importance is relativised (Johnson-DeBaufre 2005:77; cf. Vaage 2001:483). The second sentence of verse 28 is therefore not in the first place a statement about John, but about the poor and vulnerable in society. It is also not in the first place a statement about the superiority of God's kingdom in comparison with previous dispensations, but rather about the superiority of the 'least significant' (according to society) in God's kingdom compared to the 'most significant' in society at large. ${ }^{7}$ It is true that the second sentence of verse 28 is a rhetorical device employed to compare membership and non-membership in God's kingdom, but it does so by comparing the 'least significant' (according to society) in God's kingdom with the most significant in society at large. According to the new social order operative in God's kingdom, the socially marginalised are superior to those who would normally be viewed as significant in ancient society (including John). The ancient social hierarchy is turned on its head: the 'least significant' are now the 'most significant' (Johnson-DeBaufre 2005:77). ${ }^{8}$ This understanding of verse 28 squares well with other $Q$ texts, like the claim in $Q$ 6:20 that God's kingdom is for the poor and the claim in Q 10:21, 23-24 that 'children' are more fortunate than the socio-economic and politico-religious leaders of ancient Israel (JohnsonDeBaufre 2005:77; cf. Ra 2016:131, 135, 139, 149; Rollens 2014:193). ${ }^{9}$ The message to the peasantry and poor is that they are not less significant than others in society. In fact, they are the most significant people in God's kingdom.

To the extent that God's kingdom was imagined to infiltrate and replace ancient Jewish society at large, this reversed social order was expected to become the new societal norm. The belief was that as soon as God's kingdom had spread to all of Israel, 'all relative scales of evaluation will be completely rewritten' (Bock 1994:676). Just like John is favourably contrasted with royalty in Q 7:24-28, this 'kingdom for the peasantry and poor' is favourably contrasted with the existing Jewish kingdom, which exploits these people (cf. Horsley 1999:98, 240; Rollens 2014:172). However, the message is not to wait for the new kingdom to arrive at some point in the future, but to start living as if this were already the case, thereby establishing and occupying the kingdom of God as the present unfolds (cf. Bock 1994:675; Davies \& Allison 1991:252; Nolland 2005:457). The present tense of the verb 'is' ( $\dot{\varepsilon} \sigma \tau \imath)$ in verse 28 indicates that the kingdom of God is already in existence and that the socio-economic underclass is already significant within that kingdom (Joseph 2014:198-199; cf. Bock 1994:675; Davies \& Allison 1991:252; Luz 2001:139; Nolland 2005:457; Robinson 2003:31; pace Catchpole 1993:68-69). ${ }^{10}$ The message is therefore not just for others to see the peasantry and poor as significant, but also for them to see themselves as significant. As such, the text

7.This is not to say that the sentence is not also on a secondary level about the (in) significance of John, perhaps even insinuating that John finds himself outside of the kingdom, as commentators often point out. It is also not to say that the sentence is not on a secondary level about the significance of God's kingdom in general.

8.As a side note, this message challenges the leadership structures that developed subsequently in the church.

9. $10: 21,23-24$ speaks about 'children' (ví $\pi 101$ ) to reference (in part) those at the social bottom, which is interesting when considering that the parallel of $Q 7: 28$ in the Gospel of Thomas (46) features 'child' or 'little one' ( $\mu 1 \kappa \rho o ́ c)$ instead of 'least

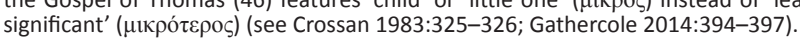

10.In reference to Q 7:24-28, Tuckett $(1996: 135$, cf. 158, 209) makes the following statement: 'John's futurist eschatology has a realised element.' 
promotes a positive and affirmative self-image among the peasantry and poor, which would obviously have all kinds of psychological benefits. There should be no doubt that the message of this $Q$ passage was directed at the underside of ancient society (Horsley 1999:296). This is not to say that those who ranked above the peasantry and poor could not also have learnt something from this message, especially with regard to what they thought of their socio-economic inferiors and how they acted towards them. These socioeconomic superiors would have been called to increase their consideration of the worthiness of the peasantry and poor. However, I remain convinced that this pericope would, in the first place, have been directed at those who were lower on the socio-economic scale and that its message would have been much more beneficial to these underlings than the rich and powerful. To my mind, this is confirmed by the derogatory statements towards the rich in the opening of the pericope.

\section{Q 10:5-9}

${ }^{5}$ Into whatever house you enter, [[first]] say: Peace [[to this house]]! ${ }^{6}$ And if a son of peace be there, let your peace come upon him; but if not, [[let]] your peace [[return upon]] you. ${ }^{7}[[$ And at that house]] remain, «eating and drinking whatever they provide», for the worker is worthy of one's reward. [[Do not move around from house to house.] ${ }^{8}$ And whatever town you enter and they take you in, eat what is set before you, ${ }^{9}$ and cure the sick there, and say [[to them]]: The kingdom of God has reached unto you. ${ }^{10}$ But into whatever town you enter and they do not take you in, on going out [[from that town]], ${ }^{11}$ shake off

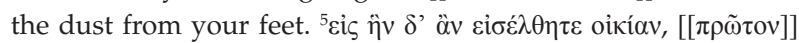

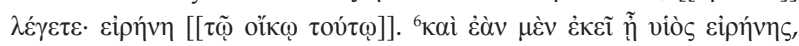

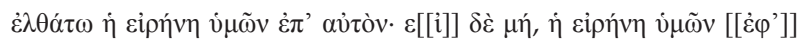

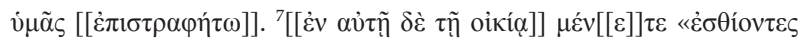

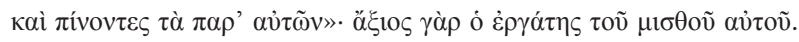

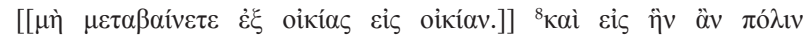

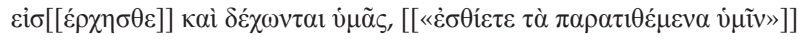

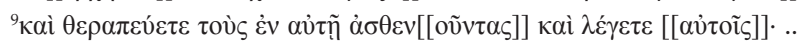

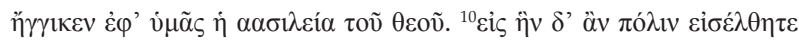

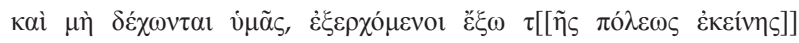

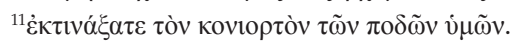

Whether Q 10:5-11 is directed at the Q people in general, missionaries, 'itinerant radicals,' Cynics or actual agricultural workers, ${ }^{11}$ it deals with hospitality (Arnal 2001:178; Bock 1996:998, 999; Fleddermann 2005:433; Joseph 2012:88; Kirk 1998:347-349, 358; Kloppenborg 2000:147; Marshall 1978:419; Piper 1989:134; 2000:243, 256; Robinson 2001a:50, 2001b:16; 2003:225; Vaage 1994:30-33; Valantasis 2005:103, 104). ${ }^{12}$ In antiquity, hospitality was the social value that managed the reception of strangers in one's home as guests (see Malina 1998a:115-118). It is important to realise that entry into someone's house equalled survival for those at the bottom of the socio-economic ladder. It goes without saying that a house offers refuge from the elements and the possibility of

11.See Howes $(2014 ; 2015: 80-81)$ for the possibility that the mission discourse was aimed at actual agricultural workers.

12.Also when the text is interpreted from the Cynic perspective, hospitality is an important (if not primary) category (see Vaage 1994:30-33). receiving lodging, ${ }^{13}$ clothing ${ }^{14}$ and food (Robinson 1995:265; 1997:225). Ancient literature specifically describes hospitality as an act performed towards the poor (e.g. m. Pe'ah 8:7). In our passage, sustenance seems to be a particularly important benefit of receiving hospitality, as is indicated not only by the

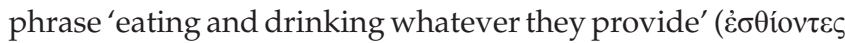

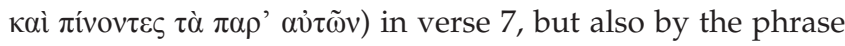

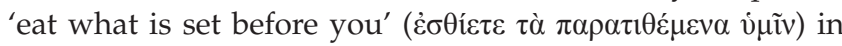
verse 8 (cf. Marshall 1978:420; Robinson 1995:265, 268). Receiving hospitality is a way of gaining entry into someone's house and receiving sustenance (Horsley 1999:240, 246; Robinson 1995:265, 268; 1997:225; cf. Bock 1996:999; Tuckett 1996:183, 288-289; 2001:374, 386, 387; 2014:62, 63). At least in part, this passage promotes seeking out hospitality as a means of survival for the poor (Robinson 1995:268; pace Arnal 2001:182; Vaage 1994:32). Although it is not spelled out, hospitality is depicted here as one of the ways in which God feeds and shelters the poor (Robinson 1995:265, 268; 1997:225; 1999:199; 2001a:33). This explains, at least in part, how Q 6:21 can claim that the hungry will be fed (Ra 2016:63). This reading of $Q$ 10:5-11 is reinforced by other $Q$ texts that describe God as taking care of his people (e.g. Q 11:9-13; 12:22-31; cf. Joseph 2012:88; Ra 2016:85; Robinson 1995:265266; 1997:236-237; 2001a:32-33, 50; 2001b:16). Although it is people who provide hospitality by opening their homes and sharing their tables, it is ultimately God who is responsible for the accommodation and nourishment received (Ra 2016:62; Robinson 1995:268; 1997:225; 2001a:33, 50; 2001b:16).

The comment in verse 7 that 'the worker is worthy of one's reward' is especially relevant to the context of poverty. The comment probably draws upon Leviticus 19:13 and Deuteronomy 24:14-15, where people are ordered to pay their workers on a daily basis before sunset without missing a day (cf. Allison 2000:224; Tuckett 1996 n. 94 - although these scholars are doubtful about this textual link). ${ }^{15}$ Like Q 10:7, the Masoretic Texts of both Leviticus 19:13 and Deuteronomy

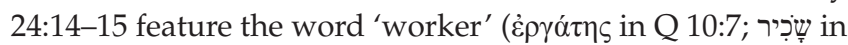
MT) together with the word 'reward' or 'wage' ( $\mu 1 \sigma \theta$ ó $\varsigma$ in

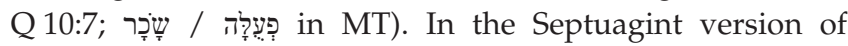

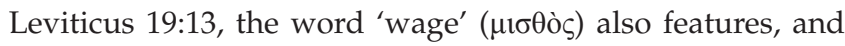
a synonym is used for the word 'worker' (i.e. $\mu 1 \sigma \theta \omega \tau$ ós). ${ }^{16}$ In the Septuagint version of Deuteronomy 24:14-15, the word

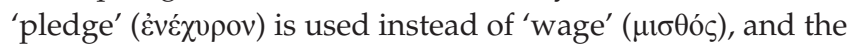

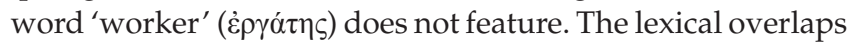
with Q 10:7 are therefore strongest for Leviticus 19:13 ${ }^{\mathrm{MT}}$ and

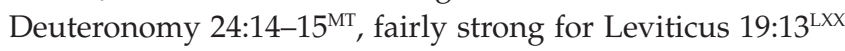
and weakest for Deuteronomy 24:14-15 ${ }^{\text {Lxx }}$. Despite these lexical variances, however, the conceptual overlap between Q 10:7 and all these versions remains. In Deuteronomy

13.Arnal's (2001:178) argument from silence that the mission discourse does not envision lodging as one of the benefits of hospitality is unconvincing. In antiquity, hospitality always included the possibility of receiving or providing shelter.

14.Although food and shelter were most commonly associated with hospitality in the ancient world, it could also include receiving or providing clothes (cf., e.g., t. Pe'ah 4:8).

15. Horsley (1999:96) sees a link with Numbers 18:30-31, but this is unlikely.

16.The use of $\mu 1 \sigma \theta \omega \tau$ ó $\zeta$ for 'worker' in Leviticus 19:13 ${ }^{\text {Lxx }}$, which derives from the

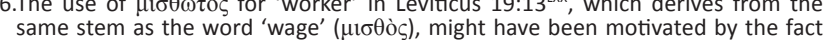

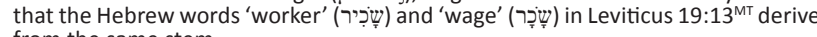
from the same stem. 
24:14-15, these workers are specifically referred to as the

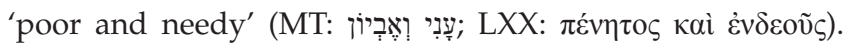
It should not come as a surprise that day-labourers are described as poor and needy, given their lowly and vulnerable position in the ancient world (cf. Bazzana 2015:302 n. 102). The Masoretic Text supports the commandment to pay the workers daily with a motive clause that is not easy to

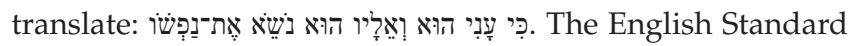
Version probably captures the meaning correctly with the following translation: 'for he is poor and counts on it.' However, something of the plight of the poor communicated by the Hebrew is lost in this translation and better captured by the more literal translation of the King James Version: 'for he is poor and has set his heart on it.' The Septuagint

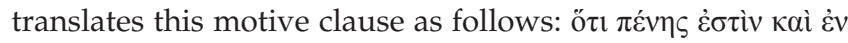

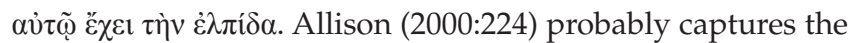
correct meaning of the Septuagint with his translation: 'because they are poor and their livelihoods depends on [it].' As with the Masoretic Text, however, a more literal translation communicates the plight of the poor more accurately: 'for he is poor and in it he has hope' (Penner et al., 2012, Deut 24:14-15). All this is to illustrate that verse 7, and Q 10:5-11 as a whole, has the poor specifically in mind (cf. Park 2014:78). The corporeal concerns of the socio-economic underclass are a definite priority for $Q 10: 5-11$, which is written from the perspective of these underlings. Reading this passage as directed at missionaries or 'itinerant radicals' does not preclude it from being interpreted in terms of poverty. Luz (2001:72), for example, states: 'The text speaks of itinerant radicals who, dirt poor and without an established residence, roam through the countryside' (cf. also Allison 2000:52, 147; Hoffmann 1972:329; Ra 2016:61; Valantasis 2005:101, 104). Yet, the current reading would fit much better if the mission discourse was aimed at actual agricultural workers (cf. Howes 2014; 2015:80-81). Although peasants could also benefit from acts of hospitality, these verses probably have those in mind who did not benefit from stable housing, meaning the poor.

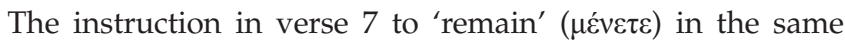

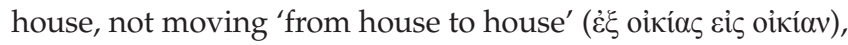
is good advice for those seeking hospitality. It prevents people from forming the impression that one is a mere drifter or otherwise unstable (Luz 2001:81; cf. Valantasis 2005:103). It also curtails the perception that one is taking advantage of people's kind nature by playing different hosts off against each other, by trying to find the most lucrative situation or by extracting as much resources as possible from everyone in the community (cf. Arnal 2001:179, 180; Davies \& Allison 1991:175; Robinson 1995:269-270; Valantasis 2005:103). Such perceptions would invite gossip (see Van Eck 2013:8-9), which could in turn jeopardise existing arrangements or future attempts at finding hospitality. The Tosefta, for example, explicitly states while discussing hospitality: 'Now, if he [referring to the guest] goes around from door to door, you [referring to the host] are not obligated to him for anything' (t. Pe'ah 4:8; cf. Arnal 2001:178, 179).
The instruction to remain at the same house is elaborated with another instruction to eat and drink 'whatever they provide' ( $\tau \grave{\alpha} \pi \alpha \rho$ ' $\alpha \hat{\tau} \tau \tilde{\omega} v)$. This latter instruction speaks not only to one of the benefits of receiving hospitality (see above) but also to the conduct of these recipients. They are advised to not be picky or abstemious eaters, pulling up their noses at the food and drink they receive, but rather to accept such forms of nourishment with gratitude and appreciation (Robinson 1995:268; cf. Arnal 2001:180; Bock 1996:999). Like the instruction to remain at the same house, this also qualifies as good advice intended to benefit the recipient of hospitality in the long run. Fussy eaters would not have been tolerated by their hosts for too long and would probably also have evoked gossip. It is no wonder that ancient instructions on table-fellowship typically advocated eating whatever is served, especially when one is the recipient of another's hospitality (Kirk 1998:348; cf. Vaage 1994:130; e.g. Ptahhotep $6: 10-7: 2)$. Not to do so would have been regarded as an insult to the host.

As forms of repayment for receiving hospitality, verse 9

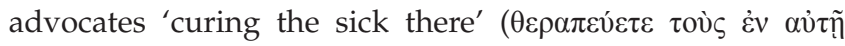

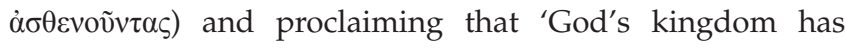

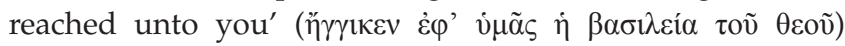
(Fleddermann 2005:434; Kloppenborg 2000:147; cf. Robinson 1995:269; 2001a:50; 2001b:16). The translation of $\eta^{\gamma} \gamma(\kappa \varepsilon v$ with 'has reached' or 'has arrived' is probably closer to its intention in this Q passage than translations like 'has drawn near' or 'has come near' (see Bock 1996:1000; Marshall 1978:422-423; cf. Q 11:20). If this is correct, it means that the kingdom of God becomes a reality in the present moment during which hospitality is received and recompensed (Joseph 2014:198-199; Robinson 2003:31; cf. Allison 2010:124; Bultmann 1994:27; Fleddermann 2005:434; Johnson-DeBaufre 2005:66, incl. esp. n. 78, 190; Vaage 1994:36; pace, e.g., Allison 2010:124; Kloppenborg 2001:166, 167; Tuckett 1996:148). The proclamation about God's kingdom should not only be understood in terms of either missionary preaching or repayment for material support but also as a description of the dealings between the parties involved. Receiving food, clothes and shelter is itself a manifestation of God's kingdom (Robinson 1999:199; 2001a:33, 50; 2001b:16; 2003:31, 35; cf. Q 6:20-21; 14:16-21, 23). Interpreters often point out that the act of 'curing the sick' in verse 9 is part and parcel of the kingdom's (present and/or future) manifestation (cf. Q 11:20), ${ }^{17}$ but typically fail to recognise that the acts of 'receiving' or 'taking in' ( $\delta \dot{\varepsilon} \chi 0 \mu \alpha)$ and 'eating' ( $\dot{\varepsilon} \sigma \theta i \omega)$ in verse 8 are likewise manifestations of the kingdom..$^{18}$ According to verses 8-9, which comprise only one sentence, the kingdom of God is manifested not only whenever and wherever the sick are healed but also whenever and wherever the less fortunate receive food, clothing and shelter (Robinson 1995:269; 1999:188, 199; 2001a:33, 50; 2001b:16; 2003:31, 35).

17.For example, Bazzana 2015:205-206, 208, 275-276, 302, 305; Bock 1996:9991001; Jacobson 1994:103; Johnson-DeBaufre 2005:65; Kirk 1998:351; Kloppenborg 1001; Jacobson 1994:103; Johnson-DeBaufre 2005:65; Kirk 1998:351; Kloppenborg
2001:166; Labahn 2014:176-177, 180; Luz 2001:75, 76; Marshall 1978:421; 2001:166; Labahn 2014:176-177, 180; Luz
Nolland 2005:417; Vaage 1994:34-36, 57-58.

18.A noteworthy exception is Robinson (1995:269; 1999:188, 199; 2001a:33; 2001b:16; 2003:31, 35). 
Robinson (2001a:50; 2001b:16) is therefore correct when he says: 'God's reign involved the hospitality itself.'

It is not coincidental that verse 6 uses the word 'son' as part of

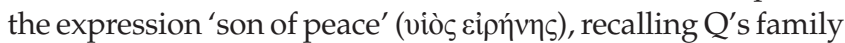
metaphor (Fleddermann 2005:433; Rollens 2014:167; cf. Park 2014:88). More directly, the word 'house' (oikía / oĩkos), which is repeated five times in this passage, also recalls Q's family metaphor (cf. Horsley 1999:246; Ra 2016:140; Robinson 1999:199). Acts of hospitality unite guests and hosts under the same roof as part of the same household, sharing the same resources. In the process, the symbolic family of God is expanded to include multiple households, thereby spreading throughout society (cf. Horsley 1999:86, 89, 248; Järvinen 2001:521; Ra 2016:63; Robinson 2001a:50; 2001b:17; cf. Q 13:18-21). In this way, God's kingdom establishes itself cumulatively through individual acts of hospitality. This process of expansion is further suggested by the structural build-up of Q 10:5-9, which begins in verses 5-7 with a single household (oíkía / oĩkos), progresses in verse 8 to a village, town or city $(\pi$ ó $\lambda$ เ $)$, and culminates in verse 9 with an entire 'kingdom' ( $\beta \alpha \sigma \imath \lambda \varepsilon i ́ \alpha)$. As a side note, the already-not yet tension in $\mathrm{Q}^{\prime} \mathrm{s}$ descriptions of God's kingdom ${ }^{19}$ should probably be understood in terms of its expansion: it had already manifested itself in the lives of many people, but had not yet infiltrated Jewish society at large (cf. Robinson 1999:199; 2003:31).

The passage makes allowance for both a positive and a negative outcome when seeking hospitality (Allison 1997:109; Bock 1996:997; Crossan 1983:111-112; Ebner 2000:128; Fleddermann 2005:432, 433, 434; Hoffmann 2001:270; Horsley 1999:87, 233, 246; Jacobson 1992:142; Kirk 1998:350, 351; Robinson 1999:188; 2001a:50; 2001b:16; Tuckett 1996:184, 287; see Vaage 1994:30-33,128). In case of a negative outcome, the passage gives the following instructions to those seeking

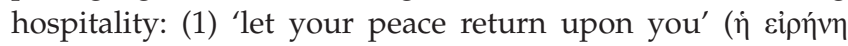
$\dot{v} \mu \tilde{\omega} \nu \dot{\varepsilon} \varphi$ ' $\left.\dot{v} \mu \tilde{\alpha} \varsigma \dot{\varepsilon} \pi \_\tau \rho \alpha \varphi \eta \dot{\tau} \omega\right)$ and (2) 'shake off the dust from

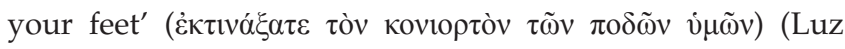
2001:81). The former instruction implies that the seekers of hospitality do not 'lose' their peace when their requests are met with rejection (Davies \& Allison 1991:176; cf. Fleddermann 2005:432-433; Nolland 2005:419; Robinson 2001a:50; 2001b:16; Vaage 1994:31). The latter instruction means to break all ties with those houses and/or towns that fail to offer hospitality (Bock 1996:1001; Davies \& Allison 1991:178Fleddermann 2005:434; Luz 2001:81; Nolland 2005:420; cf. Kirk 1998:355356). Yet, the intent behind such advice might have more to do with the emotional welfare of those seeking hospitality than the fate of those failing to offer hospitality. Hence, the instruction is for the former group not to take such rejection personally and not to become disheartened, but to soldier on in search of food and shelter (Vaage 1994:31, 33).

\section{Q 11:9-13}

${ }^{9}$ I tell you: ask and it will be given to you, search and you will find, knock and it will be opened to you. ${ }^{10}$ For everyone who asks 71, 86-87, 159-160, 201. receives, and the one who searches finds, and to the one who knocks will it be opened. ${ }^{11}$ What person of you, whose son asks for bread, will give him a stone? ${ }^{12}$ Or again when he asks for a fish, will give him a snake? ${ }^{13}$ So if you, though evil, know how to give good gifts to your children, by how much more will the Father from heaven give good things to those who ask him!

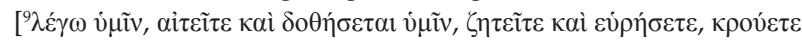

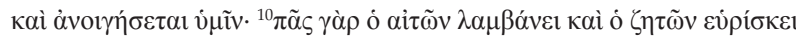

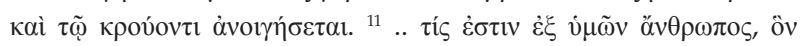

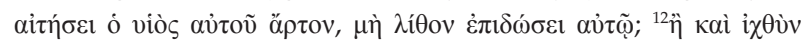

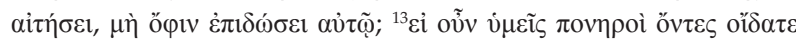

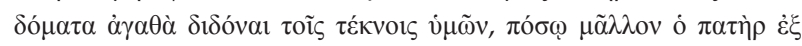

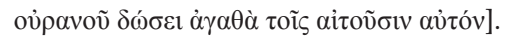

This pericope begins in verse 9 with an instruction that

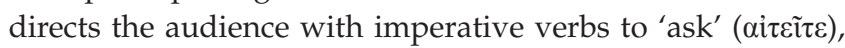

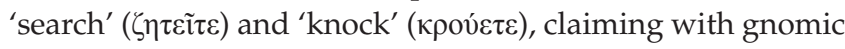
assurance that they will receive when they ask, find when they search and produce an open door when they knock (Kirk 1998:180; Kloppenborg 1987:204; Ra 2016:72; cf. Piper 1989:16-17, 21). The same claim is repeated in verse 10, with the only difference being that it is now presented without imperative verbs in the more typical form of a maxim or gnomic statement (Catchpole 1993:220; Crossan 1983:99; Nolland 2005:326; Piper 1989:21; Ra 2016:72; cf. Fleddermann 2005:472; Jeremias 1972:159; Valantasis 2005:122). As the conjunction 'for' or 'because' ( $\gamma \alpha \dot{\alpha} \rho)$ indicates, the instructions of verse 9 are supported by the (repeated) claim in verse 10 that those who ask, search and knock will (eventually) be successful (Betz 1995:502, 504, 505; Catchpole 1993:220, 223; Luz 2007:358; Marshall 1978:467; Nolland 2005:326; Piper 1989:17, 21). Considering only verses 9 and 10, the claim seems generally applicable to all contexts and circumstances, but the rest of the pericope identifies the intended meaning more specifically (Kirk 1998:180; Piper 2000:247; cf. Betz 1995:501, 504; see Piper 1989:16-17, 21).

This is particularly true of the verb 'ask' ( $\alpha i \tau \varepsilon \dot{\varepsilon} \omega)$, which is repeated in each of the subsequent verses (Jacobson 1992:158; Kirk 1998:180; Piper 1989:16, 23-24; Robinson 1998a:138-139; cf. Luz 2007:357; Nolland 2005:325; Ra 2016:73). Verse 11

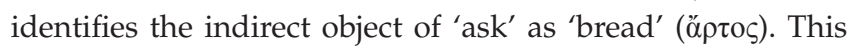
bread should be understood in the same way as the bread of the Lord's Prayer, namely as representative of food in general (Horsley 1999:266-267; Piper 2000:245). Verse 12 then

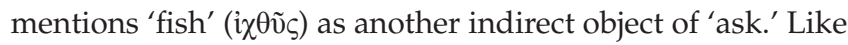
bread, fish was a staple food in antiquity and would have been particularly common around the Sea of Galilee (Betz 1995:505; Davies \& Allison 1988:682, 683; Horsley 1999:267, 296; Luz 2007:358). Hence, both bread and fish are used here as collective terms that represent 'all the necessities for sustaining life' (Betz 1995:377, cf. 399; cf. Fleddermann 2005:473; Horsley 1999:266-267, 295-296; Piper 1989:18; 2000:245, 247), and therefore 'sustenance in general' (Luz 2007:321, cf. 360; cf. Catchpole 1993:212, 225; Marshall 1978:458; Nolland 2005:290; Ra 2016:73). The verb 'ask' should in other words be understood as asking people for food in order to survive (pace Luz 2007:358). Verse 13 finally

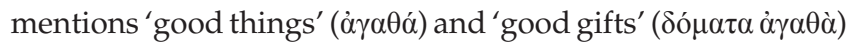


as indirect objects of 'ask.' The term 'good gifts' refers back to the bread and fish of verses 11-12, and the term 'good things' is syntactically and rhetorically parallel to the term 'good gifts' in the first part of verse 13 (Piper 1989:20). The argument is not that God will provide 'better things,' but that he will be better at providing the same things mentioned in verses 1112 (Catchpole 1993:214; Robinson 2003:30; pace Tuckett 1996:154). As Catchpole (1993:214) rightly says, 'the gifts of the heavenly and earthly fathers must match.' This is a prerequisite for the argument to work. Given these factors, the conclusion is inescapable that the 'good things' ( $\dot{\alpha} \gamma \alpha \theta \alpha$ ) and 'good gifts' ( $\delta{ }^{\prime} \mu \alpha \tau \alpha \dot{\alpha} \gamma \alpha \theta \dot{\alpha}$ ) of verse 13 refer literally to food (Catchpole 1993:213; Piper 1989:20; Robinson 2003:30). At the very least, the surrounding material indicates that the 'things' of verse 13 include goods related to survival ahead or instead of luxury or superfluous items (Piper 1989:20). This is supported by Q 12:33-34, which advocates against the attainment and accumulation of 'earthly treasures'

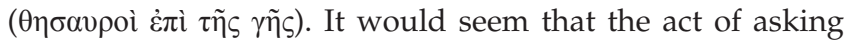
pertains in this $Q$ passage specifically to food and by extension to other basic needs (Luz 2007:360).

Much less information is provided for the verbs 'search' and 'knock.' Unlike the verb 'ask,' no objects are expressly mentioned for these verbs, and they are not repeated in verses 11-13. Some clues are nonetheless available. The verb

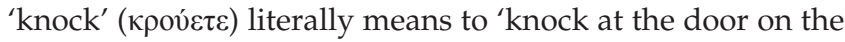

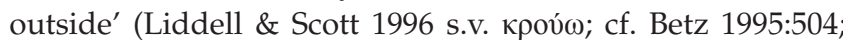
Robinson 1995:265; Valantasis 2005:121). Most people would presume that the door belongs to a house. The saying goes on

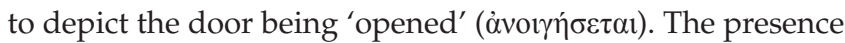
of the dative personal pronoun 'you' ( $\dot{v} \mu \mathrm{i} v)$ after the passive verb 'open' suggests that the door is opened in order to let the person who knocked inside. In other words, the imagery is that of seeking hospitality by knocking on someone's door (cf. Robinson 1995:264-265, 268, incl. n. 57; Valantasis 2005:121). Given not only that the verb 'ask' is used in this passage to reference material survival but also that hospitality is portrayed in the mission discourse as a means of securing food and shelter, it is likely that the verb 'knock' is here meant in terms of hospitality and its role in the procurement of material subsistence (cf. Robinson 1995:264-265, 268, incl. $n$. 57). ${ }^{20}$ If Luke 11:5-8 featured in the Sayings Gospel (see Catchpole 1993:201-228; Kirk 1998:177-180; cf. Piper 1989:24; Tuckett 1996:152 n. 43), it would further support our reading of 'knock' in Q 11:9-10, because hospitality is the main theme of this passage (cf. Betz 1995:504; Kirk 1988:179-180; Snodgrass 2008:441; see Catchpole 1993:201-210; Herzog 1994:199-214; Scott 1989:86-92). Significantly, Luke 11:5-8 also mentions 'bread' (áp $\tau$ os), linking hospitality explicitly with the provision of food (Catchpole 1993:218, 222, 225; cf. Kirk 1998:179-180; Piper 1989:24). In any event, Luke 11:5-8 shows that at least Luke understood 'knock' in terms of hospitality. In Q 11:9-10, a vivid picture is painted of someone

20. Piper $(2000: 245)$ distinguishes between the mission discourse and 0 . $11.9-13$. the basis that the former 'is identified with the receipt of hospitality rather than the basis that the former is identified with the receipt of hospitality rather than mo a 'knous'y with God's providential care.' However, if we are correct that the verb knock' in Q11:9-10 presumes hospitality, this distinction would dissipate. Also, it is presumed in the mission discourse that God's providential care underlie human acts of hospitality (see above) standing in front of a house, knocking at the door and the door opening (cf. Valantasis 2005:121). The unstated assumption is that the opened door would lead to food and shelter (Robinson 1995:265).

The verb 'search' is perhaps the most difficult to determine precisely. There are no explicit clues to its meaning in the pericope itself. In antiquity, the verbs 'search' and 'find' were often used in reference to truth, wisdom, philosophy and knowledge (Davies \& Allison 1988:679, 682; Luz 2007:358; cf. Allison 2000:242; Valantasis 2005:121; see Betz 1995:501-502). The Matthean context of this pericope after Matthew 7:6-11 might support the latter possibility (cf. Davies \& Allison 1988:677-678). In the Bible, the verb often features as part of expressions like 'seeking for God' (e.g. Deut 4:29; Isa 55:6; 65:1), 'seeking after God' (Acts 17:27) and 'seeking the face of God' (2 Sam 21:1; Pss 23:6; 26:8; Hos 5:15), the latter of which means to pray (Allison 2000:242; Marshall 1978:467; cf. Bock 1996:1060-1061). The problem with the latter trio of suggested intertexts is that God (or the face of God) is not mentioned as the object of 'search' in Q 11:9-10.

If one instead considers the association of 'ask' and 'knock' in Q 11:9-10 with material subsistence, a similar meaning seems likely for the verb 'search.' The latter interpretation is confirmed by Q 12:22-31, the passage that teaches against anxiety in the face of obtaining daily needs (see below). Verse 31 of this passage proclaims that these daily needs would be granted to God's children if they seek his kingdom. The verb used here for 'seeking' God's kingdom is the same verb used in Q 11:9-10 as part of the instruction to 'search,' namely

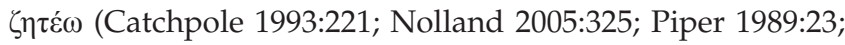
2000:258; Robinson 1995:264-265; Tuckett 1996:154 n. 52). The sentence in Q 12:31 begins with the conjunction 'but' ( $\delta \varepsilon \dot{)}$, implying that the act of seeking God's kingdom is an alternative to the anxiety over daily needs discussed in the preceding verses (cf. Tuckett 1996:153 n. 45). Although these preceding verses do not use the verb 'search' to describe the people's procurement of necessities, verse 30 does use a compound verb with the same stem when claiming that the

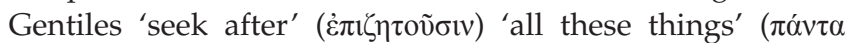
$\tau \alpha \tilde{\tau} \tau \alpha)$, referring to daily necessities. Unlike the Gentiles, who obsessively 'seek after' daily necessities, the children of God are encouraged to 'seek' God's kingdom, in which case their daily needs would be provided anyway. What is important in the current context is that $Q 12: 22-31$ develops the idea of 'searching' for daily needs, which strongly suggests that the verb 'search' in Q 11:9-10 should be understood in a similar way (cf. Piper 2000:258; Robinson 1995:264-265). As both of these texts seem to imply, the idea of 'searching' for food and other basic needs apply especially to the peasantry and poor, because others would presumably not need to 'search' for these bare necessities. As such, the use of the verb 'search' in the context of procuring sustenance would have resonated particularly with the peasantry and poor.

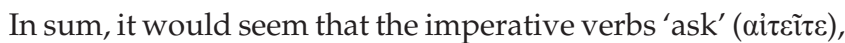

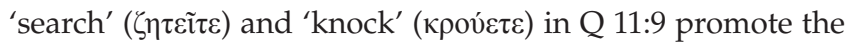
seeking of sustenance and hospitality from others as a means 
of survival (Howes 2016a:18; cf. Davies \& Allison 1988:679; Luz 2007:358, 360; Marshall 1978:467). Catchpole (1993:221) is correct in observing that if Q 11:9-10 preceded Q 11:11-13 in the Sayings Gospel, the object of the verbs ask, search and knock would be 'the material necessities of life.' Piper (1989:20) similarly states that Q $11: 9-13$ as a whole offers exhortation 'in the face of genuine concern over material support, and especially food.' In a later publication, Piper (2000:247) also states: 'The general sayings about asking in Q 11:9-10 lead quickly to specific issues about food in Q 11:1113.' The subject matter of $Q$ 11:9-10 is not really applicable to those with means, but is particularly applicable to those for whom the procurement of sustenance is a daily struggle, that is, the peasantry and poor (Horsley 1999:260, 296; cf. Catchpole 1993:228; pace Arnal 2001:43, but cf. 46-47). Whereas Q 6:30 (about giving to others without expecting anything in return) is written from the perspective of the one who gives, our current text is written from the perspective of the one who receives (cf. Betz 1995:504).

The future-tense verbs in $Q$ 11:9, namely 'will be given'

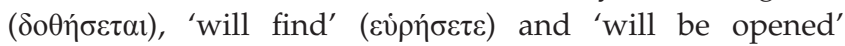

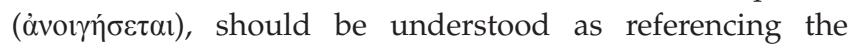
immediate future of daily living. These verbs appear in the future tense because they happen chronologically after the

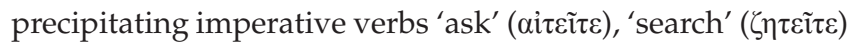

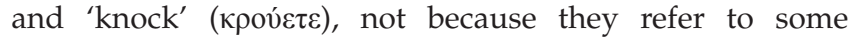
eschatological future (cf. Arnal 2001:186; Catchpole 1993:220; Kloppenborg 2001:178; Piper 2000:248; Robinson 2003:30; pace Betz 1995:504; Ra 2016:72; Tuckett 1996:154-155). This is confirmed by the subsequent verse, where the first two actions are described using the present-tense verbs 'receive'

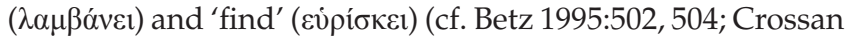
1983:99; Luz 2007:358; Piper 1989:17). The third verb, 'will be

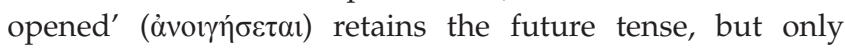
because it appears in the passive voice and therefore describes the action performed by the semantic object (i.e. the door) instead of the action performed by the semantic subject (i.e. the person knocking) (cf. Ra 2016:72; pace Catchpole 1993:219). Conversely, the first two verbs are in the active voice and therefore describe the actions performed by their respective semantic subjects. Some copiers of the New Testament found

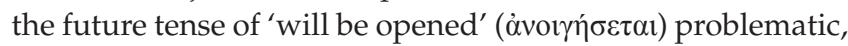
replacing it in some textual traditions of Matthew (7:8) and Luke (11:9) with the present-tense verb 'is opened' ('ंvor $\gamma \varepsilon \tau \alpha 1)$ (Bock 1996:1065; Marshall 1978:468). At any rate, in Q 11:10 the verbs appear as part of a gnomic statement with general applicability to everyday life, confirming that the immediate future of normal existence is intended by all future-tense verbs in Q 11:9-10. ${ }^{21}$ The fact that a future-tense verb is used in verse 10 as part of a gnomic statement that is so obviously directed at present reality confirms the non-eschatological interpretation of the future-tense verbs in verse 9 (cf. Catchpole 1993:220). The same is finally indicated by the fact that the verbs of verses 11-12 are also in the future tense, but

21. Betz (1995:502, 504) argues that an eschatological reading is possible in addition to a gnomic reading, but fails to support this claim with argumentation. He seems very uncertain about the eschatological reading, claiming that ' $[t]$ he future passive does not necessarily refer to the eschatological future, but it may.' indisputably function in a gnomic sense (Nolland 2005:326; cf. Piper 2000:248). If the future-tense verbs of verses 9-10 and 11-12 function non-eschatologically, then so does the future-tense verb 'will give' ( $\delta \dot{\sigma \varepsilon \imath)}$ in verse 13 (Robinson 2003:30; pace Tuckett 1996:154-155).

Whereas verses 11-12 refer to a 'person' ("丷v $\theta \rho \omega \pi \mathrm{o})$ ) as the recipient of the request, verse 13 names God with the familiar

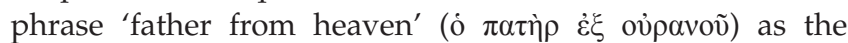
recipient of the request (Piper 1989:19; cf. Batten 1994:48; Betz 1995:504; Robinson 1995:263; 1997:249). This phrase harks back to Q 10:21 and Q 11:2, and indicates that the verb 'ask' should also in Q 11:13 be understood as a reference to prayer, with God the Father as direct object (Allison 1997:14, 15; Catchpole 1993:225; Fleddermann 2005:473; Horsley 1999:86; Jacobson 1992:159; Kirk 1998:182; Kloppenborg 2000:125; 2001:177-178; Nolland 2005:327; Ra 2016:73; Robinson 1997:248-249; Tuckett 1996:154, 280). This should not, however, be taken to mean that verses 9-10 are exclusively or even primarily about prayer (Nolland 2005:325; cf. Betz 1995:501, 504, 506; Kloppenborg 1987:205; pace, e.g. Davies \& Allison 1988:679, 684; Luz 2007:358; Marshall 1978:466-467; Tuckett 1996:152-153). It seems unlikely that three different verbs (i.e. ask, search and knock) would be used for the exact same referent (i.e. prayer), even if later tradition understood the text in this way (cf. Piper 1989:23; pace Catchpole 1993:220; Davies \& Allison 1988:679; Luz 2007:358; Marshall 1978:467). As discussed above, the verbs 'ask,' 'search' and 'knock' in verses 9-10 are in the first place references to the different ways in which the peasantry and poor secured basic needs in the ancient context. It is unlikely that the first readers and listeners would have thought of prayer ahead of subsistence when hearing these particular verbs in combination. This is especially true of the verb 'knock,' which reminds of hospitality long before it reminds of prayer. Marshall (1978:467) argues that the verb 'knock' was also sometimes used for prayer in the Jewish context, but is only able to list one intertext from later rabbinic literature to prove his point (i.e. Meg. 12b; cf. Allison 2000:242 n. 99; Bock 1996:1061).

Verses 9-10 only connote prayer to the extent that God is ultimately responsible when people respond positively to the plight of others (see below). It is therefore only on a secondary level that it is legitimate to regard the active verbs in Q 11:910 as references to prayer, and the passive verbs in these verses as divine passives (cf. Davies \& Allison 1988:679; Marshall 1978:466-467; Piper 1989:17). In fact, it is only the verb 'ask' that is developed further in verses 11-13 in relation to prayer (Piper 1989:17, 19; cf. Ra 2016:73). Verses 9-10 focus on the human response to poverty and suffering, whereas verse 13 focuses on the divine response (cf. Betz 1995:504, 506; Kirk 1998:182). Verses 11-12 represent a sort of segue, continuing the exclusive focus on the human response in verses 9-10, but doing so in order to prepare for the divine response in verse 13 (Piper 1989:17-18, 19; cf. Catchpole 1993:212; Kirk 1998:181; Robinson 1995:263). One might want to argue that the literary context requires one to read the verbs in Q 11:9-10 as exclusive references to prayer, seeing as the Lord's Prayer is likely to precede our text (directly) in the 
Sayings Gospel (cf. Allison 2000:242; Crossan 1983:97; Kloppenborg 2001:177, 178; Robinson 1997:249; 2003:30; 2005:118). Yet, in my view, the two passages are in the first place linked by the topic of material subsistence, and only on a secondary level by the more abstract topic of prayer (cf. Horsley 1999:266-267; Kloppenborg 1987:205). To the extent that both passages are about God's kingdom (cf. Horsley 1999:88, 147, 266-267, 295; Tuckett 1996:153), this kingdom should be understood in non-eschatological terms as dealing primarily with corporeal matters like food provision (Robinson 1993:1-2; 2003:30; cf. Kloppenborg 2001:178; Tuckett 1996:153 n. 45; see Horsley 1999:266-267, 295-296; Piper 2000:245-249). It is noteworthy that the Lord's Prayer uses the words 'pray' ( $\pi \rho \circ \sigma \varepsilon v ́ \chi 0 \mu \alpha)$ and 'say' $(\lambda \varepsilon \dot{\gamma} \omega)$ in reference to prayer, not the verbs of Q 11:9-10. Conversely, the two passages do share the

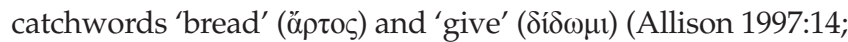
Horsley 1999:266-267; Kloppenborg 1987:205; 2000:125; 2001:177; Piper 1989:23; 2000:245; Ra 2016:73).

Considering the pericope as a whole, the divine and human meanings are not contradictory, and the text intends both (cf. Robinson 1995:263, 265; Valantasis 2005:122; pace Luz 2007:358). In fact, linking divine and human action in the feeding of people seems to be a deliberate intention of the passage (cf. Davies \& Allison 1988:678; Kloppenborg 1987:206). The listeners and readers are directed to ask both people and God for food (cf. Robinson 1995:263). The imagery of earthly parenthood is applied to God, portraying him as the heavenly Father who looks after his children (Fleddermann 2005:473; Park 2014:84, 89, 90; cf. Bock 1996:1062; Kloppenborg 2000:125; Ra 2016:73; Robinson 1998a:138; 1999:192; Zimmermann 2014:10, 27). Once again, the text appeals to Q's family metaphor (Valantasis 2005:123; cf. Kloppenborg 2001:178; Ra 2016:73). By means of a qal wahomer (or a minori ad maius) argument, this pericope reasons that if earthly fathers know how to provide good things to their children, the heavenly Father would be even better at doing this (Allison 1997:15; Arnal 2001:169; Betz 1995:502-503, 506; Bock 1996:1062; Catchpole 1993:214; Davies \& Allison 1988:684; Fleddermann 2005:472, 473; Kloppenborg 2000:125; 2001:178; Luz 2007:359; Marshall 1978:465; Piper 1989:19, 20; Ra 2016:73; Robinson 1997:249). The fatherhood of God cannot be understood by merely projecting earthly fatherhood onto the divine, because the fatherhood of God is far superior to anything that earthly fathers can achieve (Davies \& Allison 1988:683; Luz 2007:359; Valantasis 2005:123). The text gives expression to the fallibility of earthly fathers when it refers to them as 'evil'

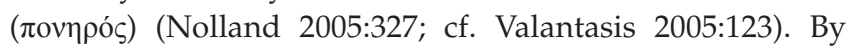
contrast, the 'heavenly Father' is portrayed here as knowing exactly what his children need and providing it for them (Fleddermann 2005:473; Jacobson 1992:159; Kloppenborg 2001:178; Valantasis 2005:123; cf. Marshall 1978:469; Nolland 2005:327; Ra 2016:73). In this way, verses 11-13 interpret the human responses to material need in verses $9-10$ as the result of God's parental love and care (cf. Kirk 1998:181; Robinson 1995:263). It is implied that all successful attempts at procuring food are attributable to divine providence (cf. Kloppenborg 2000:144). Although it is people who give to those who ask, it is ultimately God who is responsible for feeding his children, including the homeless and helpless in society (cf. Howes 2016b). As Robinson (1995:265) says, 'God answers through human action.' Whenever a beggar, day-labourer or peasant is given a piece of bread, it is as if God is extending his hand from heaven to feed one of his hungry children. Such acts of providence are described in verse 13 as 'gifts' ( $\delta$ ó $\mu \alpha \tau)$ from God.

The instruction to 'ask' does not have to be read in terms of beggary, but could also be understood in terms of ancient reciprocity. Reciprocal acts of giving and receiving would presumably in most cases be precipitated by an act of asking. I have argued elsewhere that certain texts in the Sayings Gospel Q promote general reciprocity in exchange for balanced reciprocity throughout ancient society (e.g. Howes 2013:311-315, 2016b:122-123, 2017:14, 16). ${ }^{22}$ If this is correct, it would follow that all acts of asking were in some sense actually acts of begging, because people were expected, according to this social vision, to give without expecting anything in return (cf. esp. Q 6:30, 34). However, the lack of an expectation for return does not necessarily translate into a lack of return. The giver might still get a return on investment even if she does not expect such a return. It is the expectation of return that creates animosity and tension in society. In other words, general reciprocity does not equal no reciprocity, but rather eliminates those elements of balanced reciprocity that tend to create tension, gossip, harassment, oppression and unequal relationships in society. Yet, this does not mean that beggary is excluded as a potential reference of the verb 'ask.' The likelihood that the verb 'knock' refers to hospitality supports the idea that the verb 'ask' connotes beggary. Such a reading of the verb 'ask' also makes better sense of the verb 'search,' because the act of searching for sustenance is perhaps most intelligible within the context of beggary. Hence, the verb 'ask' probably includes both reciprocity and beggary in its purview, especially considering that $Q$ promotes general reciprocity, which blurs the lines between reciprocity and beggary.

As we saw, Q 11:9-10 claims that 'all' ( $\pi \tilde{\alpha} \varsigma)$ those who ask, search and knock will be successful in their attempts to secure basic necessities. Rhetorically, this claim seems to be based on human experience (Betz 1995:502, 504, 507; cf. Davies \& Allison 1988:679; see Piper 1989:21-22; pace Marshall 1978:467-468; Nolland 2005:326). A number of commentators have struggled with the veracity of this claim, maintaining that it seems 'unjustified when measured against actual practice' (Kirk 1998:180; cf. also Luz 2007:359). Such unease has caused some to regard this claim as an exaggeration of reality (e.g. Betz 1995:505; Piper 1989:22), and others to narrow its intended focus (see Luz 2007:359-360; e.g. Catchpole 1993:219-220; Tuckett 1996:154-155). Yet, the claim of our passage is not that those who ask, search and knock

22.'Balanced reciprocity, can be defined as barter and other (economic) exchanges ( that are characterised by expectations and/or obligations of equal return, in the spirit of fairness and justice (Horsley 1995b:204; Oakman 1986:66). Conversely, 'general reciprocity' can be defined as barter and other (economic) exchanges that are characterised by the unilateral giving or receiving of something without any expectations and/or obligations of repayment, in the spirit of grace and benefaction (Oakman 1986:151-152; 2008:95, 105, 138; cf. Luke 11:11). 
are always and in all circumstances successful, but that all $(\pi \tilde{\alpha} \varsigma)$ those who do so are successful (cf. Betz 1995:505). These people may not be successful every time, but experience and observation seem to confirm that all of them are successful enough to survive. The text intends the latter, not the former. Interpreters often overlook this subtle difference. Instead of being hyperbolic, the text merely claims that those who ask, search and knock do generally tend to find food, clothes and shelter, even if many (or perhaps even most) individual attempts might be unsuccessful (cf. Betz 1995:505). One has to agree that all people have at least once in their lives been successful at each of the three actions, namely asking, searching and knocking. An affirmative answer to the latter minimalist scenario is all that is needed for the claim in Q 11:10 to be logically true. Yet, most would agree that the success rate is much higher than this.

The claim that asking, searching and knocking will (eventually) lead to positive results might have been closer to the truth in antiquity than it would be in a modern context. Practices like hospitality and village communalism (cf. Arnal 2001:114), together with a worldview that focused on groups instead of individuals (see Kissi \& Van Eck 2017:321-323; Malina 1993:63-89; Neyrey 1998:94-98), would have made it easier for people in the ancient world to rely on the generosity of others for survival. The claim that those who ask, search and knock are successful would therefore not necessarily have been mere wishful thinking in an ancient context. This is not to claim that conditions were easy for the peasantry and poor in ancient society. The mentioning in verse 13 of

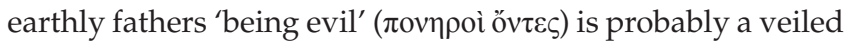
reference to the general cruelty and heartlessness of humanity (Piper 1989:20; cf. Betz 1995:505-506). The point, however, is that in the midst of such societal callousness, people are still able to rely on the goodness of others to secure basic necessities (Betz 1995:506, 507; Davies \& Allison 1988:683; cf. Nolland 2005:327). Even in a modern context, the ability of those who beg on street corners and at traffic lights to sustain themselves supports the notion that they are indeed successful at securing enough for survival.

Attempts to narrow the scope of the claim in verse 10 to the followers of Jesus, the $Q$ group or the early church go against the most obvious meaning of the text, especially the inclusive 'everyone' ( $\pi \tilde{\alpha} \varsigma$ ) in verse 10 (Luz 2007:358; pace Catchpole 1993:212; Davies \& Allison 1988:680; Tuckett 1996:155 n. 53; Valantasis 2005:120-123). Instead, the rhetoric seems to be similar to that of $Q$ 6:35: just like God provides sunshine and rain to good and bad people alike, God provides food and shelter to all. It is true that the appeal to God's fatherhood in Q 11:13 recalls the family metaphor of $Q$, which was a way of defining the in-group (see Valantasis 2005:120-123). Nolland (2005:326) argues: 'Venturing with God is open to all, but to do so places one in the position of being a child of the heavenly Father.' He continues to maintain that 'the supportive argument in [Mat 7:9-11; i.e. Q 11:11-13] bases itself on what must at least be an implicit recognition of the fatherhood of God on the part of the hearers.' This harmonisation of the universal and specific dimensions of the text is commendable. However, if we are correct to read Q 11:9-13 in combination with Q 6:35, it would follow that the providence of God is not conditional upon the recognition of God or his fatherhood, because God provides for the good and bad (or believing and unbelieving) alike. On the other hand, in Q 6:35 both the conjunction 'so that' (ö $\pi \omega \varsigma$ ) and the subjunctive verb 'may become' $(\gamma \varepsilon \dot{\varepsilon} \eta \sigma \theta \varepsilon)$ indicate that being a child of God was conditional for $\mathrm{Q}$. In my view, there is a more satisfying solution to this tension underlying both $Q$ 6:35 and Q 11:9-13. Whereas God is portrayed by both these texts as providing for the basic material needs of all people, he is not portrayed as the Father of all people. God provides for his children because they are his children and he loves them as such (Fleddermann 2005:473; cf. Valantasis 2005:123). The text does not explain overtly why God provides for other people as well. He might do so because it is his responsibility as creator. $Q$ 6:27-28, 35 would seem to imply that God does so because he also loves people who are not his children, including those who oppose him. Whatever the reason, both Q 6:35 and Q 11:9-13 portray God as providing for the bare necessities of all people. Implicit here is another qal wahomer argument: if God provides for all people, how much more would he not provide for his own children.

According to Jeremias ([1952] 1972:159), Q 11:10 'springs from the mind of the beggar: he has only to persist, to take no refusal, be unscared by abuse, and he will receive a gift' (cf. Davies \& Allison 1988:679). The example in Luke 11:5-8, which precedes this pericope in Luke (and perhaps in Q), teaches that persistent prodding will inevitably prove successful (Bock 1996:1060; pace Catchpole 1993:222). It is true that $Q$ 11:9-13 fails to emphasise or even mention perseverance, which can therefore not be regarded as the hermeneutical key that will unlock this passage (Catchpole 1993:222; Marshall 1978:467). Yet, even if perseverance is not the (main) message of the logia in Q 11:9-10, the listeners and readers would instinctively have known that in order for asking, searching and knocking to yield results, persistence would more often than not be required. At any rate, the general success of the peasantry and poor to procure food, clothing and shelter is interpreted in Q 11:9-13 as a sign of God's providence (Betz 1995:507). Given such divine providence, the peasantry and poor are directed to ask others and actively search for food, shelter and other necessities. Q 11:9-13 further promotes making use of the ancient social value of hospitality to secure these bare necessities. In addition to directing the peasantry and poor to rely on others for support, the passage encourages them not to lose heart in the midst of their daily struggle for survival, promising that God will provide (Piper 1989:20, 22; 2000:234, 245, 256, 258; cf. Allison 1997:15; Davies \& Allison 1988:684; Kloppenborg 2001:178). In other words, the peasantry and poor are encouraged to rely on God for their survival (Ra 2016:73; Robinson 1997:237, 238, 246; 1999:192; 2001a:32, 49; 2001b:16; cf. Arnal 2001:193). The text inspires 'remarkable confidence' that God will provide for his children (Crossan 1983:98). In this regard, the intent of Q 11:9-13 is almost identical to the 
content of Q 12:22-31, where people are instructed not to be anxious in their attempts to secure daily necessities, but to rely on God (Davies \& Allison 1988:684; Kloppenborg 1987:206; 2001:178; cf. Robinson 1995:264-265; 1997:237, 238, 246; 1999:192; 2001a:32-33; see Piper 2000:234, 244-245, 258).

Although the term 'kingdom of God' is not mentioned in this text, and the concept is not explicitly developed (Piper 2000:247), Tuckett (1996:153) is probably correct that Q 11:913 presumes and reaches back to the mentioning of God's kingdom in the Lord's Prayer (cf. Horsley 1999:88, 147, 266-267, 295; Kloppenborg 2001:178; Robinson 1993:1-2). In addition to being related to material subsistence and Q's family metaphor, the concept of God's kingdom is here developed in another sense. ${ }^{23}$ As we saw, God is depicted in Q 11:9-13 as taking care of the physical needs of all people, not only his children. God's provision crosses group boundaries, and his family is implicitly expected to follow their Father's example in this regard (cf. Q 6:35). This is perhaps supported by the fact that this text refers to the

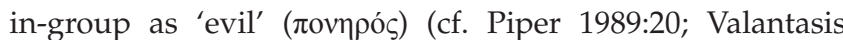
2005:123). Is part of the reason that they are called evil possibly that they only support each other's material needs, and not those of outsiders? Valantasis (2005:123) asks the question differently: 'Are the readers part of the corrupt family that gives good things only to its own members, or are they part of the larger heavenly family where requests receive appropriate and immediate response?' To my mind, this line of enquiry reveals how the $\mathrm{Q}$ people imagined the kingdom of God spreading throughout Jewish society (and perhaps the world), namely by treating outsiders like insiders and thereby involving them in God's family. This corresponds to how I interpreted Q 6:27-28, 35 elsewhere (Howes 2016a:21):

The social vision of $Q^{\prime} s$ formative stratum starts in the inaugural sermon with the directive in Q 6:27 to love one's enemies. In the ancient world, love was more than just an emotion; it was primarily an expression of group attachment and bonding (see Malina 1998[b], 127-130). The instruction to love one's enemies therefore means to include them within one's own social group, and treat them like insiders (cf. Malina 1998[b], 129). The end result of such a process would be that everyone becomes part of God's extended family through mutual love and caring behaviour.

\section{Findings}

In Q 7:24-28, the peasantry and poor are told that they matter, and that they are not less important than the rich and powerful. In God's kingdom, they are actually more important. In Q 10:5-9, the poor are encouraged to seek out hospitality from others in order to survive. They are given practical advice to improve not only their short-term chances at procuring food and shelter, but also their long-term chances at retaining support from others. In doing so, they

23.As part of his argument against Tuckett (1996:154-155), who believes that the object of the verbs 'ask,' 'search' and 'knock' is the eschatological kingdom of God, Piper (2000:247) draws a distinction between God's kingdom and subsistence, claiming that $Q 11: 9-13$ is about the latter, not the former. Although Piper is surely correct that $Q$ 11:9-13 does not presume some futurist eschatology, his distinction between the kingdom and subsistence seems to be based on a false dichotomy. In $Q$, the kingdom the sick in the present (see above). As Q 10:8-9 indicates, announcing God's kingdom simultaneously established God's kingdom, so that people were fed and cured at the same time that the kingdom was being announced. are participating in the important task of spreading God's kingdom. In Q 11:9-13, the peasantry and poor are further encouraged to rely on the support of others in order to survive. God employs the kindness of others to provide for his children. It is through such acts of kindness, hospitality and giving that the kingdom of God materialises in the lives of the peasantry and poor, spreading throughout society in the process. These messages are particularly relevant to the concerns of socio-economic underlings, and not really applicable to the concerns of those at higher socio-economic levels. Unfortunately, we do not know how the peasantry and poor actually responded to these messages.

\section{Acknowledgements}

It is a real honour for me to dedicate this article to Eben Scheffler, whose concern for the poor and marginalised shines through in his research.

\section{Competing interests}

The author declares that he has no financial or personal relationships which may have inappropriately influenced him in writing this article.

\section{References}

Allison, D.C., 1997, The Jesus tradition in Q, Trinity, Harrisburg, PA.

Allison, D.C., 2000, The intertextual Jesus: Scripture in Q., Trinity, Harrisburg, PA.

Allison, D.C., 2010, Constructing Jesus: Memory, imagination, and history, BakerAcademic, Grand Rapids, MI.

Arnal, W.E., 2001, Jesus and the village scribes: Galilean conflicts and the setting of Q., Fortress, Augsburg, MN.

Batten, A.J., 1994, 'More queries for Q: Women and Christian origins,' BTB 24, 44-51. https://doi.org/10.1177/014610799402400202

Bazzana, G.B., 2015, Kingdom of bureaucracy: The political theology of village scribes in the Sayings Gospel Q, Peeters [BETL 274], Leuven.

Betz, H.D. (A.Y. Collins [ed.]), 1995, The Sermon on the Mount: A commentary on the Sermon on the Mount, including the Sermon on the Plain (Matthew 5:3-7.27 and Luke 6:20-49), Fortress [Hermeneia], Minneapolis, MN.

Bock, D.L., 1994, Luke 1:1-9:50, Baker [Baker Exegetical Commentary on the New Testament], Grand Rapids, MI.

Bock, D.L., 1996, Luke 9:51-24:53, Baker [Baker Exegetical Commentary on the New Testament], Grand Rapids, MI.

Bultmann, R., [1913] 1994, 'What the saying source reveals about the early Church', in J.S. Kloppenborg (ed.), The shape of Q: Signal essays on the Sayings Gospel, Fortress, Minneapolis, MN, pp. 23-34.

Casey, P.M., 2002, An aramaic approach to Q: Sources for the Gospels of Matthew and Luke, Cambridge University Press [SNTSMS 122], Cambridge.

Catchpole, D.R., 1993, The quest for Q, T\&T Clark, Edinburgh.

Cromhout, M., 2015, 'Jesus and his band of rebellious sons in Q: In conversation with Jerome H Neyrey,' presented at the Wim Weren Symposium on the Gospel of Matthew, Pretoria, 22 p., 27 January.

Crossan, J.D., 1983, In fragments: The aphorisms of Jesus, Harper \& Row, San Francisco, CA.

Davies, W.D. \& Allison, D.C., 1988, A critical and exegetical commentary on the Gospel according to Saint Matthew, Volume I: Introduction and commentary on Matthew I-VII, T\&T Clark [ICC], London, New York.

Davies, W.D. \& Allison, D.C., 1991, A critical and exegetical commentary on the Gospe according to Saint Matthew, Volume II: Commentary on Matthew VIII-XVIII, T\&T Clark [ICC], London, New York.

Ebner, M., 2000, 'Feindesliebe - Ein Ratschlag zum überleben?: Sozial- und religionsgeschichtliche Überlegungen zu Mt 5,38-47 par Lk 6, 27-35', in J.M. Asgeirsson, K. de Troyer \& M.W. Meyer (eds.), From quest to Q: Festschrift James M. Robinson, pp. 119-142, Leuven University Press \& Peeters, Leuven.

Fleddermann, H.T., 2005, Q: A reconstruction and commentary, Peeters [Biblical Tools and Studies 1], Leuven.

Freyne, S., 2000, Galilee and Gospel: Collected essays, Mohr Siebeck [WUNT 125], Tübingen.

Gathercole, S.J., 2014, The Gospel of Thomas: Introduction and commentary, Brill [Texts and Editions for New Testament Study 2], Leiden, NL \& Boston, MA. 
Hartin, P.J., [1991] 2015, James and the 'Q' Sayings of Jesus, Bloomsbury [JSNTSup 47], London.

Herzog, W.R., 1994, Parables as subversive speech: Jesus as pedagogue of the oppressed, Westminster \& John Knox, Louisville, KY.

Hoffmann, P., 1972, Studien zur Theologie der Logienquelle, Verlag Aschendorf [NTAbh NF 8], Munich

Hoffmann, P., 2001, 'Mutmassungen uber Q: Zum Problem der literarischen Genese von $Q^{\prime}$ ', in A. Lindemann (ed.), The sayings source $Q$ and the historical Jesus, $\mathrm{pp}$ 255-288, Leuven University Press \& Peeters [BETL 158], Leuven.

Horsley, R.A., 1995a, 'Social conflict in the synoptic Sayings Source Q,' in J.S. Kloppenborg (ed.), Conflict and invention: Literary, rhetorical and social studies on the Sayings Gospel Q, pp. 37-52, Trinity, Valley Forge, PA.

Horsley, R.A., 1995b, Galilee: History, politics, people, Trinity, Valley Forge, PA.

Horsley, R.A. (with J.A. Draper), 1999, Whoever hears you hears me: Prophets, performance, and tradition in Q, Trinity, Harrisburg, PA.

Howes, L., 2013, “'Placed in a hidden place”: Illuminating the displacement of Q 11:33, 34-35', Neotestamentica 47(2), 303-332.

Howes, L., 2014, 'Advice for farm workers: A radical rereading of the so-called mission discourse', presented at the Society of Biblical Literature (SBL) Annual Meeting (Q Program Unit), San Diego, CA, 22 November.

Howes, L., 2015, Judging $Q$ and saving Jesus: Q's contribution to the WisdomApocalypticism debate in historical Jesus studies, AOSIS, Cape Town, ZA, viewed 06 February 2018, from http://books.aosis.co.za/index.php/ob/catalog/book/21

Howes, L., 2016a, “'Your father knows that you need all of this": Divine fatherhood as socio-ethical impetus in Q's formative stratum', Neotestamentica 50(1), 7-31, viewed 09 February 2018, from http://journals.co.za/content/journal/10520/EJC $808 \mathrm{cf} 16 \mathrm{a} 2$

Howes, L., 2016b, 'Food for thought: Interpreting the parable of the loyal and wise slave in Q 12:42-44,' in D.F. Tolmie (guest ed.), Acta theologica supplementum 23 : Perspectives on the socially disadvantaged in early Christianity, pp. 110-130, Sun Media, Bloemfontein, viewed n.d., from http://apps.ufs.ac.za/kovsiejournals/ default.aspx?article $=2864$

Howes, L., 2017, “"Make an effort to get loose": Reconsidering the redaction of $Q$ 12:58-59', Pharos Journal of Theology 98, 1-29, viewed 12 February 2018, from http://www.pharosjot.com/current-and-past-editions.html

Jacobson, A.D., 1992, The First Gospel: An introduction to Q, Polebridge, Sonoma, CA.

Jacobson, A.D., [1982] 1994, 'The literary unity of Q,' in J.S. Kloppenborg (ed.), The shape of Q: Signal essays on the Sayings Gospel, pp. 98-115, Fortress, Minneapolis, $\mathrm{MN}$.

Jacobson, A.D., 2000, 'Jesus against the family: The dissolution of family ties in the Gospel tradition', in J.M. Asgeirsson, K. de Troyer \& M.W. Meyer (eds.), From Quest to Q: Festschrift James M. Robinson, pp. 189-218, Leuven University Press \& Peeters [BETL 146], Leuven.

Järvinen, A., 2001, 'Jesus as a community symbol in Q', in A. Lindemann (ed.), The Sayings Source $Q$ and the historical Jesus, pp. 515-521, Leuven University Press \& Peeters [BETL 158], Leuven.

Jeremias, J. (transl. Hooke, S.H.), [1952] 1972, The parables of Jesus, 3rd rev. edn. SCM, London.

Johnson-DeBaufre, M., 2005, Jesus among her children: $Q$, eschatology, and the construction of Christian origins, Harvard University Press [Harvard Theological Studies 55], Cambridge, MA

Joseph, S.J., 2012, Jesus, $Q$, and the Dead Sea scrolls: A Judaic approach to $Q$, Mohr Siebeck [WUNT 333], Tübingen.

Joseph, S.J., 2014, The nonviolent Messiah: Jesus, Q, and the Enochic tradition, Fortress, Minneapolis, MN.

Kirk, A., 1998, The composition of the Sayings Source: Genre, synchrony, and wisdom redaction in Q, Brill [NovTSup 91], Leiden, NL.

Kissi, S. \& Van Eck, E., 2017, 'An appeal to personality in Hebrews: A social-scientific study', Neotestamentica 51(2), 315-335. https://doi.org/10.1353/neo.2017.0016

Kloppenborg, J.S., 1987, The formation of Q: Trajectories in ancient wisdom collections, Fortress [SAC], Philadelphia, PA.

Kloppenborg, J.S., 1991, 'Literary convention, self-evidence and the social history of the Q people', in J.S. Kloppenborg \& L.E. Vaage (eds.), Early Christianity, $Q$ and Jesus, pp. 77-102, Scholars Press [Semeia 55], Atlanta, GA.

Kloppenborg Verbin, J.S., 2000, Excavating Q: The history and setting of the Sayings Gospel, Fortress, Minneapolis, MN.

Kloppenborg Verbin, J.S., 2001, 'Discursive practices in the Sayings Gospel Q and the quest of the historical Jesus', in A. Lindemann (ed.), The Sayings Source $Q$ and the historical Jesus, pp. 149-190, Leuven University Press \& Peeters [BETL 158], Leuven.

Labahn, M., 2014, “'Was Lücken berichten: Exemplarische Beobachtungen zu narrativen gaps" in Q', in D.T. Roth, R. Zimmermann \& M. Labahn (eds.), Metaphor, narrative, and parables in Q (dedicated to Dieter Zeller on the occasion of his 75th birthday), pp. 163-188, Mohr Siebeck [WUNT 315], Tübingen.

Louw, J.P. \& Nida, E.A. (eds.), 1993., Greek-English Lexicon of the New Testament based on semantic domains: Volume 1 (domains), Bible Society of South Africa, Cape Town, ZA.

Liddell, H.G. \& Scott, R. (revised and augmented by Jones, H.S. \& McKenzie, R.), 1996 A Greek-English Lexicon, 9th edn., Clarendon, Oxford.

Luz, U. (trans. Crouch, J.E. \& ed. Koester, H.), 2001, Matthew 8-20: A commentary, Fortress [Hermeneia], Minneapolis, MN.
Luz, U. (Crouch, J.E., trans.; Koester, H., ed.), 2007, Matthew 1-7: A commentary, Fortress [Hermeneia], Minneapolis, MN.

Malina, B.J., 1993, The New Testament World: Insights from cultural anthropology, rev. edn., Westminster \& John Knox, Louisville, KY.

Malina, B.J., 1998a, 'Hospitality', in J.J. Pilch \& B.J. Malina (eds.), Handbook of Biblical social values, pp. 115-118, Hendrickson, Peabody, MA.

Malina, B.J., 1998b, 'Love', in J.J. Pilch \& B.J. Malina (eds.), Handbook of Biblical socia values, pp. 127-130, Hendrickson, Peabody, MA.

Marshall, I.H., 1978, The Gospel of Luke: A commentary on the Greek text, Paternoster [NIGTC], Exeter.

Moxnes, H., 2003, Putting Jesus in his place: A radical vision of household and kingdom, Westminster \& John Knox, Louisville, KY.

Neyrey, J.H., 1998, 'Group orientation', in J.J. Pilch \& B.J. Malina (eds.), Handbook of Biblical social values, pp. 94-98, Hendrickson, Peabody, MA.

Nolland, J., 2005, The Gospel of Matthew: A commentary on the Greek text, William B. Eerdmans [NIGTC], Grand Rapids, MI.

Oakman, D.E., 1986, Jesus and the economic questions of his day, Edwin Mellen [Studies in Bible and Early Christianity Series 5], Lewiston, ME.

Oakman, D.E., 2008, Jesus and the peasants, Cascade Books [Matrix: The Bible in Mediterranean Context 4], Eugene, OR.

Park, I., 2014, 'Children and slaves: The metaphors of Q,' in D.T. Roth, R. Zimmermann \& M. Labahn (eds.), Metaphor, narrative, and parables in $Q$ (dedicated to Dieter Zeller on the occasion of his 75th birthday), pp. 73-91, Mohr Siebeck [WUNT 315], Tübingen.

Penner, K.M., Brannan, R., Loken, I., Aubrey, M., \& Hoogendyk, I. (eds.), 2012. The Lexham English Septuagint, Lexham Press, Bellingham, WA.

Piper, R.A., 1989, Wisdom in the Q-tradition: The aphoristic teachings of Jesus, Cambridge University Press [SNTSMS 61], Cambridge.

Piper, R.A., 2000, 'Wealth, poverty, and subsistence in Q', in J.M. Asgeirsson, K. de Troyer \& M.W. Meyer (eds.), From quest to Q: Festschrift James M. Robinson, pp. 219-264, Leuven University Press \& Peeters [BETL 146], Leuven.

Ra, Y., 2016, Q, the first writing about Jesus, Wipf \& Stock, Eugene, OR.

Robinson, J.M., 1993, 'The Jesus of the Sayings Gospel Q', presented at the Institute for Antiquity and Christianity Occasional Papers 28, Claremont, CA, $18 \mathrm{p}$.

Robinson, J.M., 1995, 'The Jesus of Q as liberation theologian', in R.A. Piper (ed.), The Gospel behind the Gospels: Current studies on Q, pp. 259-274, Brill [NovTSup 75],

Robinson, J.M., 1996, 'Building blocks in the social history of Q', in E.A. Castelli \& H. Taussig (eds.), Reimagining Christian origins: A colloquium honoring Burton $L$. Mack, pp. 87-112, Trinity, Valley Forge, PA.

Robinson, J.M., 1997, 'Galilean upstarts: A sot's cynical disciples?', in W.L. Petersen J.S. Vos \& H.J. de Jonge (eds.), Sayings of Jesus, canonical and non-canonical: Essays in honour of Tjitze Baarda, pp. 223-249, Brill [NovTSup 89], Leiden.

Robinson, J.M., 1998a, 'The Matthean trajectory from Q to Mark', in A.Y. Collins (ed.), Ancient and modern perspectives on the Bible and culture: Essays in honor of Han Dieter Betz, pp. 122-154, Scholars Press [Scholars Press Homage Series 22] Atlanta, GA.

Robinson, J.M., 1998b, 'The sequence of Q: The Lament over Jerusalem', in V.J. zum Christus (ed.), Christologische Studien (Festgabe für Paul Hoffmann zum 65. Geburtstag), pp. 225-260, Walter de Gruyter [Beihefte zur Zeitschrift für die neutestamentliche Wissenschaft 93], Berlin.

Robinson, J.M., 1999, 'From safe house to house Church: From Q to Matthew', in M Becker \& W. Fenske (eds.), 'Das Ende der Tage und die Gegenwart des Heils.' Begegnungen mit dem Neuen Testament und seiner Umwelt: Festschrift für HeinzWolfgang Kuhn zum 65. Gebirtstag, pp. 183-199, Brill [AGJU 44], Leiden.

Robinson, J.M., 2001a, 'The critical edition of $Q$ and the study of Jesus', in A. Lindemann (ed.), The Sayings Source $Q$ and the historical Jesus, pp. 27-52, Leuven University Press \& Peeters [BETL 158], Leuven.

Robinson, J.M., 2001b, 'The image of Jesus in $Q$ ', in M. Meyers \& C. Hughes (eds.), Jesus then and now: Images of Jesus in history and Christology, pp. 7-25, Trinity, Harrisburg, PA.

Robinson, J.M., 2003, 'Jesus' theology in the Sayings Gospel Q', in D.H. Warren, A.G. Brock \& D.W. Pao (eds.), Early Christian voices: In texts, traditions and symbols (essays in honor of François Bovon), pp. 25-43, Brill [Biblnt 66], Leiden.

Robinson, J.M., Hoffmann, P. \& Kloppenborg, J.S. (eds.), 2000, The critical edition of $Q$ Fortress [Hermeneia], Minneapolis, MN.

Robinson, J.M., Hoffmann, P. \& Kloppenborg, J.S. (eds.), 2002, The Sayings Gospel Q in Greek and English with parallels from the Gospels of Mark and Thomas, Fortress [CBET 30], Minneapolis, MN.

Rollens, S.E., 2014, 'Conceptualizing justice in Q: Narrative and context', in D.T. Roth R. Zimmermann \& M. Labahn (eds.), Metaphor, narrative, and parables in Q (dedicated to Dieter Zeller on the occasion of his 75th birthday), pp. 93-113, Moh Siebeck [WUNT 315], Tübingen.

Schottroff, L., 1995, 'Itinerant prophetesses', in R.A. Piper (ed.), The Gospel behind the Gospels: Current studies on Q, pp. 347-360, Brill [NovTSup 75], Leiden.

Schröter, J., 2001, 'The son of man as the representative of god's kingdom: On the interpretation of Jesus in Mark and Q', in M. Labahn \& A. Schmidt (eds.), Jesus, Mark and Q: The teaching of Jesus and its earliest records, pp. 34-68, T\&T Clark, London.

Scott, B.B., 1989, Hear then the parable: A commentary on the parables of Jesus, Fortress, Minneapolis, MN. 
Snodgrass, K.R., 2008, Stories with intent: A comprehensive guide to the parables of Jesus, William B. Eerdmans, Grand Rapids.

Theissen, G., 1986, 'Das “schwankende Rohr" (Mt 11,7) und die Gründungsmünzen von Tiberas', ZDPV 101, 43-55.

Tuckett, C.M., 1996, Q and the history of early Christianity: Studies on Q, T\&T Clark Edinburgh.

Tuckett, C.M., 2001, 'The son of man and Daniel 7: Q and Jesus', in A. Lindemann (ed.), The Sayings Source $Q$ and the historical Jesus, pp. 371-394, Leuven University Press \& Peeters [BETL 158], Leuven.

Tuckett, C.M., 2014, 'Q and family ties', in D.T. Roth, R. Zimmermann \& M. Labahn (eds.), Metaphor, narrative, and parables in $Q$ (dedicated to Dieter Zeller on the occasion of his 75th birthday), pp. 57-71, Mohr Siebeck [WUNT 315], Tübingen.

Vaage, L.E., 1994, Galilean upstarts: Jesus' first followers according to Q, Trinity, Valley Forge, PA.
Vaage, L.E., 2001, 'Jewish scripture, $Q$ and the historical Jesus: A cynic way with the word?', in A. Lindemann (ed.), The Sayings Source $Q$ and the historical Jesus, pp. 479-495, Leuven University Press \& Peeters [BETL 158], Leuven.

Valantasis, R., 2005, The new Q: A fresh translation with commentary, T\&T Clark, New York.

Van Aarde, A.G., 2014, 'The love for the poor neighbour: In memory of her (Mt 26:6$13)^{\prime}$, presented at the perspectives on the socially disadvantaged in early Christianity conference, Bloemfontein, $25 \mathrm{p}$.

Van Eck, E., 2013, 'When Patrons are Patrons: A social-scientific and realistic reading of the parable of the feast (Lk 14:16b-23)', HTS Theological Studies 69(1) 14, viewed 14 February 2018, from http://www.hts.org.za/index.php/HTS/article/view/1375

Zimmermann, R., 2014, 'Metaphorology and narratology in Q exegesis: Literary methodology as an aid to understanding the $Q$ text', in D.T. Roth, R. Zimmermann \& M. Labahn (eds.), Metaphor, narrative, and parables in Q (dedicated to Diet on the occasion of his 75th birth lay), pp. 3-30, Mohr Siebeck [WUNT 315], Tubingen. 